\title{
High-rise construction in historical cities through the example of Saint Petersburg
}

\author{
Maria Granstrem $^{1 *}$, Milena Zolotareva ${ }^{1}$ and Tatyana Slavina ${ }^{1}$ \\ ${ }^{1}$ Saint Petersburg State University of Architecture and Civil Engineering, Department of History and \\ Theory of Architecture, 4 Vtoraya Krasnoarmeyskaya str., Saint Petersburg, 190005, Russia
}

\begin{abstract}
The article sets forth results of the landscape visual analysis of the interaction of high-rise construction facilities with the environment of historical urban spaces. A toxic connection of high-rise construction facilities with the established urban landscape was analyzed and recorded. One of the latest stages of the reconstruction of historical cities, which penetrated many European countries at the end of the $20^{\text {th }}$ century, also started in the beginning of the $21^{\text {st }}$ century in Russia, where the reconstruction of historical facilities and territories became one of the leading trends of architectural activity. Therefore, problems of the interaction between the old city and new high-rise construction nearby historical centers are extremely relevant for Russian architects. Specific features of Russian high-rise construction within visual borders of historical cities, developed at the turn of the $20^{\text {th }}-21^{\text {st }}$ centuries, repeat past urban-planning mistakes spread in Europe in the second half of the $20^{\text {th }}$ century. High-rise construction in close proximity to historical centers of cities violates an established scale and destroys a historical city silhouette.
\end{abstract}

\section{Introduction}

Unique historical districts of major European and Russian cities occupy only a small part of city-wide territories. In Saint Petersburg, the historical urban nucleus occupies 5\% of the territory, but it is the environment of historical districts that creates a unique image of the city as the system of interrelated and interacting signs and archetypes which form stable spatial ideas about the specific historical space.

One of the latest booms of the selective reconstruction of historical cities, which penetrated many European countries at the end of the $20^{\text {th }}$ century, started almost at the same time in Russia as well. It conditioned reconstruction as one of the leading trends of architectural activity [1]. Therefore, the issue of the interaction between the old and new is extremely relevant. Appearance of new high-rise dominants in so-called "gaps" of the historical center, as well as high-rise construction within visual borders of the historical development takes on special significance. Specific features of high-rise construction in historical cities, developed in Russia at the turn of the $20^{\text {th }}-21^{\text {st }}$ centuries, repeat past urbanplanning mistakes spread in Europe in the second half of the $20^{\text {th }}$ century. Scientifically

\footnotetext{
${ }^{*}$ Corresponding author: arch project@bk.ru
} 
substantiated planned reconstruction of fragments of historical territories is aimed at improving the comfort of living while retaining unique features of these fragments [2].

Almost all European capitals experienced adverse effects of high-rise construction within visual borders of historical cities. For example, the standard Parisian development, formed by rental houses in the late $19^{\text {th }}$ century, began to lose its architectural and urbanplanning unique character starting from the end of the 1950s in the forefront of keen enthusiasm for modern geometrized architecture "from glass and concrete". Construction of high-rise buildings also was qualified as a "modernity" feature. For example, in the late 1960s, the competition of projects for the reconstruction of the central market of Les Halles ("The Belly of Paris") represented, among others, proposals based on the "enrichment" of the historical environment with high-rise dominants [1]. For example, J. Faugeron proposed to locate five towers in the historical center, height of which would reach forty-sixty floors. Thus, the historical development was doomed to serve as a background for new high-rise buildings. The radical project of Faugeron was not approved, but, nevertheless, in 1969, the construction of the 150-meter Montparnasse tower started; it became the first dominant violating the historical architectural landscape (Figure 1).

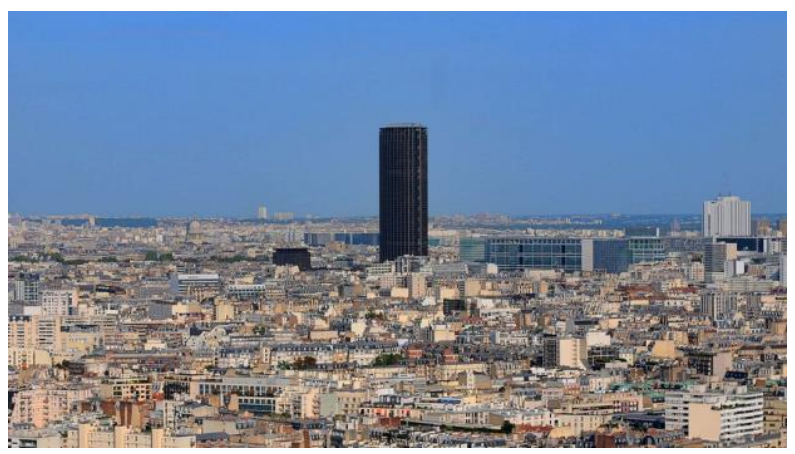

Fig. 1. Montparnasse tower in Paris

Two years earlier in Leningrad, first high-rise facilities, i.e. Sovietskaya and Leningrad hotels, were built by the $50^{\text {th }}$ anniversary of the Great October Socialist Revolution [2]; with their rectangular forms, they were the first to violate the skyline of the city's historical part (Figure 2). The construction of these facilities laid the foundation for high-rise construction both in the historical urban nucleus and in close proximity to the historical center.

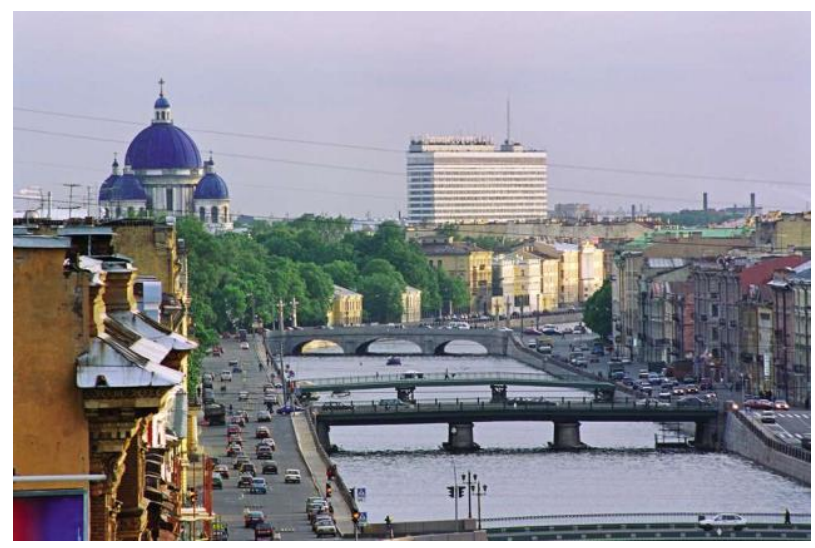

Fig. 2. Sovietskaya hotel in the Fontanka River panorama 
The purpose of this study is the landscape visual analysis of the interaction of high-rise construction facilities with the environment of historical urban spaces of Saint Petersburg. For this purpose, volumetric and spatial features of characteristic morphological units of the city were identified and connections between new high-rise construction facilities and the established urban landscape were analyzed.

\section{Materials and methods}

Central districts of Saint Petersburg represent the complex unity of the architectural and planning structure created over the period of $18^{\text {th }}-20^{\text {th }}$ centuries. It is characterized by the historical and cultural continuity, which determines the effective development of urban processes, allowing perceiving the urban planning experience and reproducing it in the light of the complication of the overall structure, functional contents and social processes [3]. Due to the established social and economic conditions, Saint Petersburg for a long time remained a city retaining its volumetric and spatial identity and its own urban-planning pattern code [4]. To carry out the analysis of the development of the system of high-rise dominants in the historical center of the city, the territory along banks of the Neva water area was determined as the most significant within the volumetric and spatial layout of the city. Urban and natural landscapes of the urban areas along embankments of the Neva, Bolshaya Nevka and Malaya Neva rivers, forming a part of the historical urban nucleus of Saint Petersburg, were studied. Spatial characteristics of this territory have the optimal balance of town-forming, local high-rise dominants with the mass of the background development and landscape, which have developed gradually in accordance with historical stages of urban planning [5]. The natural component is determined by the interaction of water spaces and green lands (parks, garden squares, squares). The Neva River serves as the center of landscape composition in this part of the city. The coherent architectural landscape of the city developed during three centuries due to the strict urban-planning discipline. Even in Petrine times, numerous imperial decrees and orders determining height restrictions, were in force in the new capital. City planners paid special attention to the silhouette of Saint Petersburg throughout several centuries; balance between the standard development and accents — urban dominants — was though through [6].

Central districts of Saint Petersburg represent the complex unity of the architectural and planning structure created over the period of $18^{\text {th }}-20^{\text {th }}$ centuries. The unique character of the city silhouette component in the layout spatial system of the city is determined by [7]:

- landscape: flat relief of the lowland area near the Neva river;

- face of the Neva river: the main composition axis of the city, forming architectural ensembles of the city center;

- compositional separation of the central and peripheral parts of the city, differing in spatial-planning qualities, including the distribution of dominants of various levels.

The historical skyline of Saint Petersburg is included into the list of 100 World Heritage sites [8] in danger; this is a way to attract the attention of the global community to problems of Saint Petersburg as a World Heritage site. Studies of the historical and urban-planning evaluation of the urban center sites and carrying out the qualitative assessment of the highrise environment of selected areas in the city center served as the reference material for the development of the landscape visual analysis of the modern state of the altitude zoning system of the city's historical center [9]. Principles of the altitude arrangement of the territory under consideration, as well as connections of its zones and separate objects with the urban landscape, urban-forming elements of the city's central part, as well as dominants of regional and local significance were recorded and analyzed; spaces under construction representing valuable elements of the historical environment or introducing dissonance into the structure arrangement of the territory under consideration were revealed. 
Thus, this study is based on revealed specific features of the modern state of urban landscapes within the boundaries of the considered territory.

\section{Results}

The analysis of the collected material made it possible to carry out the qualitative assessment of the Saint Petersburg center environment in order to reveal the system for the altitude zoning of its territories. As a result of the research, authors identified main types of urban-planning mistakes destroying the volumetric and spatial integrity of the city and the identity of the historical environment. The urban-planning mistake is the distortion of the historically established stable environment or unique compositional solution. Thus, such interference in the historical environment, which changes specific features and, due to new high-rise construction, levels down the role of historical dominants, can be considered as an urban-planning mistake.

In accordance with this definition, the typology of urban-planning mistakes is the following:

- Location of a new object within the visual area of a unique ensemble.

- Changes in the historical city silhouette.

- Scaling-up of new dominants relative to the scale of the historical development.

- Replication of a unique technique in new high-rise construction, leveling down the role of historical specific features or dominants.

The location of a new object in the visual area of an ensemble is often observed in historical parts of cities. In Saint Petersburg, cases of architectural and urban-planning violations, related to the introduction of high-rise dominants into the environment of historical river panoramas, are observed [10]. Here, results of the unscientific approach to solving the complex problem of combination of "new" and "old" are much in evidence. A typical example is the appearance of the Lakhta Center building within the historical river panorama of the Peter and Paul Fortress [11]. The building is located at a considerable distance from the historical part of the city, and, due to its height $(462 \mathrm{~m})$, it can be viewed from various points of the city center (Figure 3).

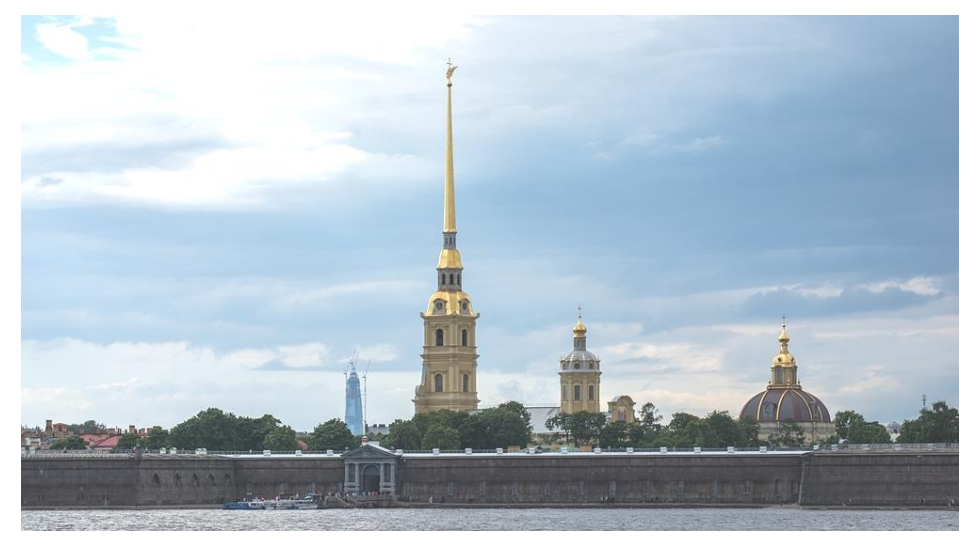

Fig. 3. Lakhta Center Building in the historical panorama of the Peter and Paul Fortress

Long before the beginning of skyscraper construction, experts developed a model according to which the skyscraper should be viewed beyond the Peter and Paul Cathedral, if an observer is on the Trinity Bridge; from this point it would be slightly smaller in height than the Grand Ducal Burial Vault. When viewed from the Palace Embankment, the skyscraper would be almost the same height as the northern rostral column [12]. No one 
respected the experts' opinion in 2011, and the Lakhta Center is built in $9 \mathrm{~km}$ from the Peter and Paul Fortress. It is already obvious that almost the entire Senate Square, a third of the Palace Square, the main part of the Palace Embankment, one third of the Peter and Paul Fortress, the whole Makarov Embankment, and Tuchkov Bridge got into its area of influenceAn example of changes in the historical silhouette with high-rise development building is shown in Figure 4. The silhouette of the classic portico of the Stock Exchange building facade at the Spit of Vasilyevsky Island is replaced by the rough outline of the administrative building built in the same visual corridor as the historical ensemble.

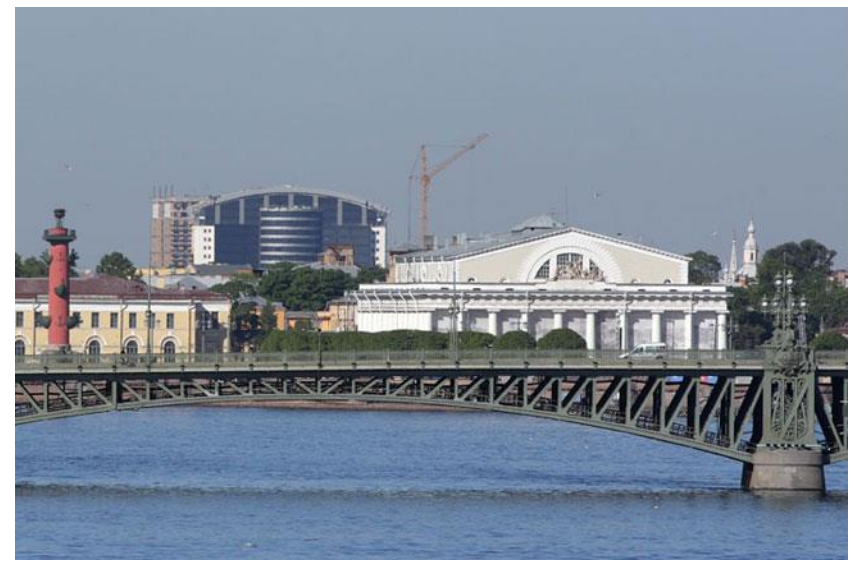

Fig. 4. Spit of the Vasilyevsky Island with the silhouette of the high-rise development building

The scaling-up of new dominants relative to the scale of the historical development negatively affects the volumetric and spatial integrity and characteristics of the identity of historical buildings. Smooth facades of new structures with almost no details conflict with small plastic arts of historical buildings, reducing their significance.

A typical example of such approach is the Mont Blanc residential complex, built in 2003-2008 at the Pirogovskaya embankment. A large-scale object exceeding the surrounding historical background development in height has a "spreading" silhouette, which is untypical for historical Saint Petersburg (Figure 5). Invading the panorama of the Neva embankment, it suppresses the historical silhouette line.

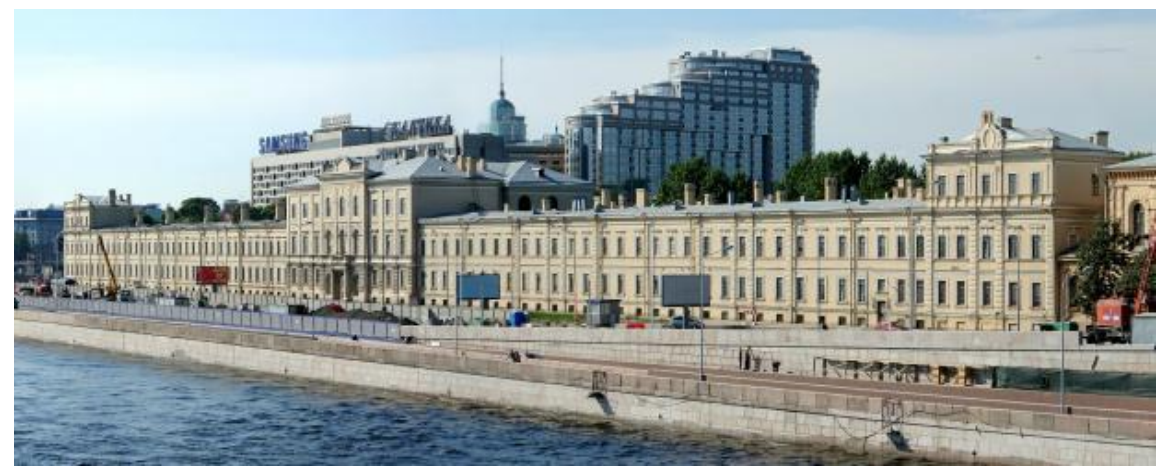

Fig. 5. Mont Blanc residential complex in the historical panorama of the Pirogovskaya embankment

Another example is the Aurora luxury residential complex (2005) near the building of the former School House of Peter the Great (Figure 6). The historical object is visually 
suppressed by large-scale forms of the high-rise structure located on the opposite bank of the Neva river.

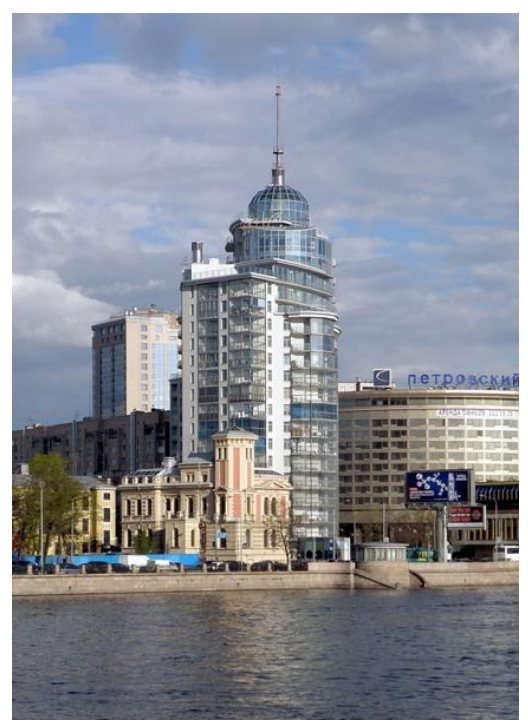

Fig. 6. Aurora residential complex

Replication of a unique technique in new high-rise construction is presented in the architecture of the Aurora residential house. It is a technique, widespread in the modern practice, allowing to join new and old by repeating some forms of a "historical neighbor" in a new building [13]. However, this technique leads to the opposite result: the architectural significance of the historical object is reduced. The crowning tower of this large high-rise building clearly reminds the cupola-spire top of the School House (Figure 7). This largescale "look-alike" makes the low historical building to seem even lower and the role of one of the dominants of the Neva panorama is reduced practically to zero [1].

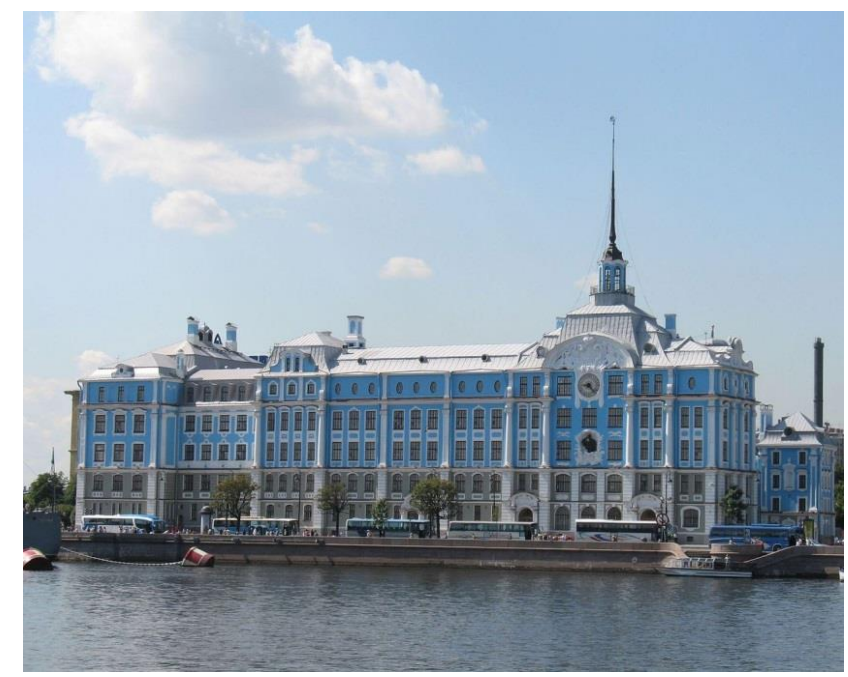

Fig. 7. School House building

\section{Discussion}


The Saint Petersburg silhouette, or skyline, is unique. Silhouette lines of the Neva embankment, small rivers and canals, historical streets and squares are one-of-a-kind and distinctive, forming the image of the city [14]. The uniqueness of central districts of Saint Petersburg is based on the contrast between the city silhouette dominants and the contour line of the established residential background development, within which a unique hierarchy of city-wide and local specific features is established.

Studies of the historical and urban-planning evaluation of the urban center sites and carrying out the qualitative assessment of the high-rise environment of selected areas in the city center served as the reference material for the development of the landscape visual analysis of the modern state of the altitude zoning system of the historical urban nucleus [9]. Principles of the altitude arrangement of the territory under consideration, as well as connections of its zones and separate objects with the urban landscape, urban-forming elements of the city's central part, as well as dominants of regional and local significance were recorded and analyzed [15]. Thus, this study is based on revealed specific features of the modern state of urban landscapes within the boundaries of the considered territory.

These reference materials allowed working out a differentiated approach to the study of volumetric and spatial features of forming high-rise dominants of the historical center of Saint Petersburg.

The study allowed making the following conclusions:

- all types of high-rise construction within the historical center should not affect the perception of town-forming ensembles and unique panoramas formed by the silhouette of the background development;

- high-rise construction buildings should not result in the replacement of historically formed morphotypes of the development with newly developed ones;

- upon the construction of high-rise buildings, not only the retaining of the city's spatial arrangement as a whole should be taken into account, but also the retaining of conditions for the perception of internal spaces of historical streets.

The practical application of the study is determined by its use in the following directions:

- development of historical and urban-planning, as well as historical and architectural expert examinations of urban territories;

- activities of state heritage protection bodies, ministries and departments which control and regulate the construction activity in the territory of cities, municipal districts and regions.

Central districts of Saint Petersburg represent the complex unity of the architectural and planning structure created over the period of $18^{\text {th }}-20^{\text {th }}$ centuries. Its creation is characterized by the historical and cultural continuity, which determines the effective development of urban processes, allowing perceiving the urban planning experience and reproducing it in the light of the complication of the overall structure, functional contents and social processes.

\section{Conclusions}

The conducted study allowed making the following conclusions:

1. Historical patterns of the development of the high-rise dominants system in SaintPetersburg were formed in accordance with the principle of historical continuity of the city's spatial-planning structure.

2. The high-rise arrangement of the historical center of the city was formed on the basis of natural conditions typical for Saint Petersburg. 
3. The carried-out analysis showed that the arrangement of city's historical dominants is naturally connected with the Neva waterline, towards which city's festive panoramas are opening.

4. One of specific features of high-rise construction in Saint Petersburg is the fact that the highest buildings (except for the 462-meter tower of the Lakhta Center) are residential complexes, unlike high-rise buildings of functional use in other countries of the world.

5. Connections between historical dominants and objects of new high-rise construction located in overlapped air corridors are revealed.

6. Further designing of high-rise construction objects shall rely on the principle of preserving territories of the stable historical part, which implies the elimination of differences between the historical environment and modern environment, conditioned by common regularities of formation, similar proportions and, mainly, a single scale.

The authors determined future directions for studies in this field. It seems necessary to conduct the comprehensive analysis of the influence of visual landmarks - new high-rise construction objects built outside the historical center, facing directly the Neva river, as well as appearing deep in the territory and sealing the city. A hypothesis about the unfavorable influence of new and to-be-built high-rise construction objects in the formation of the image of modern Saint Petersburg and its facades in the western and eastern parts is offered.

Table 1. Influence of high-rise objects on the historical city environment (through the example of Saint Petersburg)

\begin{tabular}{|c|c|c|c|c|}
\hline & \multicolumn{4}{|c|}{ Influence on the historical city } \\
\hline & $\begin{array}{l}\text { Distortion } \\
\text { of the } \\
\text { historical } \\
\text { silhouette }\end{array}$ & $\begin{array}{l}\text { Changes in } \\
\text { the role of } \\
\text { historical } \\
\text { dominants }\end{array}$ & Scaling-up & $\begin{array}{c}\text { Replication of } \\
\text { techniques typical } \\
\text { for the historical } \\
\text { environment }\end{array}$ \\
\hline $\begin{array}{l}\text { 1. Local dominants of } 1960- \\
\text { 1980s (Sovietskaya and } \\
\text { Leningrad hotels) }\end{array}$ & & & & \\
\hline $\begin{array}{l}\text { 2. Residential buildings and } \\
\text { business centers constructed } \\
\text { in } 1990-2000\end{array}$ & & & & \\
\hline $\begin{array}{l}\text { 3. Residential buildings } \\
\text { of } 2000-2017 \text {, introduced in } \\
\text { main river panoramas of the } \\
\text { city }\end{array}$ & & & & \\
\hline $\begin{array}{l}\text { 4. Lakhta Center } \\
\text { (construction completion - } \\
2018 \text {, building height }-462 \\
\mathrm{~m} \text { ), located at the distance of } \\
\text { about } 10 \mathrm{~km} \text { from the } \\
\text { historical urban nucleus }\end{array}$ & & & & \\
\hline
\end{tabular}

\section{References}

1. M. A. Granstrem. Are scientific methods for the reconstruction of fragments of historical cities real? Architectural Almanac, 1, 71-78 (2016).

2. S. V. Sementsov. Stages of urban development of Saint Petersburg and typology of 
master plans of $18^{\text {th }}-20^{\text {th }}$ centuries. Reconstruction of Saint Petersburg 2003, 93-98 (2003).

3. M. V. Zolotareva. Le Vieux Pétersbourg — L'animation d'une zone protégée. Monuments Historiques, 179, 87-88 (1992).

4. S. P. Zavarikhin. About the silhouette and not just that. Kapitel, 1, 34-37 (2012).

5. J. Kurbatov, V. Gorunov. The fate of the creative legacy in modern architecture in Russia. Bulletin of Civil Engineers, 23 (13), 203-206 (2013).

6. M. V. Zolotareva. New trends of urban development in Russia in the $18^{\text {th }}$ century. Journal of Architecture and Urbanism, 41 (1), 71-77 (2017).

7. M. V. Zolotareva. Identification of historical patterns in the development of the highrise dominants system in the central part of Saint Petersburg (based on works of artists and graphic artists of the $18^{\text {th }}$-early $19^{\text {th }}$ centuries). Modern science: theoretical and practical views, 105-109 (2014).

8. M. A. Granstrem, M. V. Zolotareva. Analysis of the structure of the historical development in Saint Petersburg. Zhilishchnoe Stroitelstvo, 11, 23-26 (2014).

9. R. T. Clement. A history of Russian architecture. Library Journal, 129: 12, 77 (2004).

10. M. V. Zolotareva On the issue of regulation of architectural and construction process in city management structure (second half of the xix - early $\mathrm{xx}$ centuries). Architecture and Engineering, 1(3), 41-46 (2016). DOI: https://doi.org/10.23968/2500-0055-2016-1-3-41-46

11. Yu. I. Kurbatov. Petrograd. Leningrad. Saint Petersburg: lessons of architecture and urban-planning. (2008).

12. URL: http://kanoner.com/2011/03/14/21565/

13. S. P. Zavarikhin. Modern construction in the historical center of Saint Petersburg. Modern Problems of History and Theory of Architecture, 115-122 (2015).

14. D. Shvidkovsky, E. Shorban, A. Wood. Russian architecture and the West, Yale: Yale University Press (2007).

15. M. V. Zolotareva. Stages of the Saint Petersburg center formation in works of artists of the $18^{\text {th }}-19^{\text {th }}$ centuries. Bulletin of Civil Engineers, 5 (52), 30-39 (2015). 